\title{
The meaning of feedback: medical students' view
}

\author{
O significado do feedback: um olhar de estudantes de medicina
}

\begin{tabular}{|c|c|}
\hline Silvia Cristina Marques Nu & dro \\
\hline Edna Regina Silva Pereira & ersp13@gmc \\
\hline Nilce Maria da Silva Campos Costa' & nilcecosta58@gmail.com \\
\hline Marcos Rassi Fernandes ${ }^{1}$ & mar \\
\hline
\end{tabular}

\begin{abstract}
Introduction: The teaching-learning process in health involves a binomial: on the one hand, teaching (the teacher and the institution) and, on the other hand, the students and their ability to adequately interact in this context. Just as teaching requires specific skills, learning also requires students to be able to master the necessary skills for learning. Feedback should also be understood in this regard. Although feedback is a frequent topic in the literature, few studies have addressed its meaning and impact from the students' perspective. Moreover, a gap has been identified between theory and practice regarding the real power of feedback in the teaching-learning process.
\end{abstract}

Objective: This study aimed to assess medical students' understanding of feedback.

Method: This is a qualitative research with a descriptive and exploratory focus, carried out using in the case study modality, with the focus group technique in data collection and thematic content analysis. The participants were medical students attending the fourth-year or eighth-semester at three schools located in the state of Goiás, Brazil.

Results: The following categories emerged: understanding of feedback, frequency of received feedback, impact of feedback on the teachinglearning process and perception about the received feedback. Students understood in part the concept of feedback, not recognizing the internal feedback. A low frequency of feedback was reported and depended on the teacher, subject and year/semester of the course related to the type of curriculum. Even so, the participants recognized the points of feedback that impact on the teaching-learning process and were receptive to effective feedback.

Conclusion: Even though they knew the meaning of feedback only partially and experienced it irregularly, medical students recognized the impact of this tool on the teaching-learning process. In a context of students trained to know about their own knowledge, truly empowering them in the teaching-learning process, they will develop a constant reflective practice of generating internal feedback, allowing the actual impact of feedback on the teaching-learning process to be observed in practice, as described in the literature.

Keywords: Feedback; Students Medical; Teaching; Learning; Educational Measurements.

\section{RESUMO}

Introdução: O processo ensino-aprendizagem em saúde envolve um binômio: por um lado, o ensino (o docente e a instituição) e, por outro, o aluno e sua capacidade de interagir adequadamente nesse contexto. Assim como o ensinar demanda competências específicas, o aprender também exige dos alunos a capacidade de dominar as habilidades necessárias à aprendizagem. O feedback também deve ser entendido nesse sentido. Apesar de o feedback ser um tema frequente na literatura, poucas pesquisas abordam o seu significado e impacto na perspectiva dos discentes. Além disso, existe uma lacuna entre a literatura e a prática sobre o seu poder real no processo de ensino-aprendizagem.

Objetivo: Este estudo objetivou avaliar a compreensão de feedback por alunos de cursos de Medicina.

Método: Trata-se de uma pesquisa qualitativa com enfoque descritivo e exploratório, na modalidade de estudo de caso, com a utilização da técnica de grupo focal na coleta de dados e análise de conteúdo temática. Os participantes foram discentes do quarto ano ou oitavo período de três faculdades de Medicina localizadas no estado de Goiás.

Resultado: As seguintes categorias emergiram: compreensão de feedback, frequência do feedback recebido, impacto dele no processo de ensinoaprendizagem e percepção sobre o feedback recebido. Os alunos compreenderam parcialmente o conceito de feedback, mas não reconheceram o feedback interno. Foi relatada uma baixa frequência de feedback e de sua relação com o professor, a disciplina e o tempo no curso relacionado ao tipo de currículo. Mesmo assim, os estudantes reconheceram os pontos impactantes do feedback no processo de ensino-aprendizagem, estando receptivos ao feedback efetivo.

Conclusão: Embora conhecessem apenas parcialmente o significado de feedback e o vivenciassem de forma irregular, os estudantes de Medicina reconheceram o impacto dessa ferramenta no processo ensino-aprendizagem. Num contexto de alunos capacitados em conhecer sobre seu próprio conhecimento, verdadeiramente os emponderando no processo de ensino-aprendizagem, eles desenvolverão uma prática reflexiva constante de gerar o feedback interno, possibilitando que o impacto real do feedback no processo de ensino-aprendizado possa ser observado na prática conforme descrito na literatura.

Palavras-chave: Retroalimentação Psicológica; Estudantes de Medicina; Ensino; Aprendizagem; Avaliação Educacional.

1 Universidade Federal de Goiás, Goiânia, Goiás, Brazil.

Chief Editor: Rosiane Viana Zuza Diniz. $\quad$ | Associate Editor: Maurício Abreu Pinto Peixoto.

Received on 11/10/20; Accepted on 07/11/21. | Evaluated by double blind review process. 


\section{INTRODUCTION}

The learning process is how human beings acquire new knowledge, develop skills and change behavior. Some learnings can be considered innate, but most of the learning takes place in the social environment in which the individual lives. In the educational area, teaching techniques can contribute to the learning process, mainly linked to basic learning: learning to learn, learning to do, learning to be and learning to live together'.

According to the National Curriculum Guidelines (NCG), the undergraduate student must be co-responsible for their learning in the initial, continuing and in-service training, highlighting the importance of learning to learn². Learning to learn is related to the competence of information understanding, assimilating, interpreting and applying it in practice; developing the knowledge construction skill by playing an active role in their own learning ${ }^{1,3}$. In this context of continuing learning, the importance of the constant feedback practice emerges ${ }^{1}$.

Feedback is specific information about the comparison between the observation of a student's performance or knowledge when performing a task and the desired standard. It seeks to improve this performance and reduce the distance between the ideal and the factual ${ }^{4,5}$. Feedback is considered effective when it is capable of generating results, promoting a positive and desirable development ${ }^{6,7}$.

During the active feedback process, the teacher is responsible for the role of facilitator (choosing the appropriate task, establishing desired standards and helping the process of reflective practice). In this model, the academic task stipulated by the teacher (evaluation or not) is the starting point of the process ${ }^{8}$.

Engaging in this task requires the student to mobilize their prior knowledge, motivation and adequate interpretation of what the purpose of the proposed task is. Thus, they can reformulate their own objectives with the task, by applying tactics and strategies to fulfill their mission, thus generating results. Internal feedback results from the comparison of individual progress, self-goals, and a defined standard. External feedback comes to be the trigger and to increase, agree or get into a conflict with the taken learning path. As the next step, actions are put into place to fill out the spaces between them, directing and consolidating knowledge ${ }^{8}$.

With this reflective practice, the student can go through the stages of the competence awareness theory (unconscious incompetent, conscious incompetent, conscious competent and unconscious competent) described in Kolb's cycle, mainly from the first to the second stage $e^{9,10}$.

By mobilizing internal learning processes, feedback becomes a metacognitive learning process. The term metacognition appeared in the 1970s with Flavell, being defined as the person's knowledge, awareness and control of their own's cognitive processes ${ }^{11}$. It translates into the learner's capacity to consciously identify what they have learned and what they still need to learn, as well as making use of resources to meet their learning needs, becoming an important part of the teaching-learning process ${ }^{12,13}$.

The teaching-learning process in health involves a binomial: on the one hand, teaching (the teacher and the institution) and, on the other hand, the student and their capacity to adequately interact in this context. Just as teaching demands specific skills, learning also requires from students the ability to master the skills that are necessary for learning ${ }^{3}$.

Feedback must also be understood in this sense. Although this strategy has the capacity to considerably influence the teaching-learning process ${ }^{4,6,14-17}$, some studies state that it occurs rarely or ineffectively, especially in medical education ${ }^{18-23}$. Would it be that this gap does not correlate with the end stage of this process, i.e., student learning? Therefore, the aim of this study was to assess the understanding of feedback by medical students.

\section{METHOD}

\section{Study design}

The present research was characterized as a qualitative study with a descriptive and exploratory approach. The case study modality was chosen, using the focus group technique in data collection and thematic content analysis ${ }^{24-31}$.

The qualitative research works with the universe of meanings, motives, aspirations, perceptions, beliefs, values and attitudes as part of the human social reality, since human beings are not characterized only by their actions, but by thinking about them and interpreting them within the lived context ${ }^{30}$. This understanding is crucial when exploring the experiences and perceptions of students in health education research ${ }^{26}$.

The case study is characterized as a type of research of which object is a unit, which is analyzed in depth and in a more directed way. By involving two or more subjects, two or more institutions, one can speak of multiple cases. The choice of the unit to be investigated is made considering the problem or question that concerns the investigator, aiming at a detailed examination of a particular situation, which in this study is: feedback in the medical course in the state of Goiás, Brazil ${ }^{25,27}$.

The main characteristic of the focus group technique lies in the fact that it works with the reflection expressed by the participants' speech, allowing them to simultaneously present their concepts, impressions and conceptions about a given topic. Moreover, one can capture the human tendency to form 
opinions and to take attitudes when interacting with other individuals ${ }^{28,29}$. Focal groups are, therefore, appropriate for exploratory research, that is, research in areas that are poorly understood or in need of a better definition ${ }^{28}$.

The thematic content analysis process, on the other hand, consists in the set of discourse analysis techniques aimed at obtaining, through systematic and objective procedures, the inference about the thematized content in the focus group discussions, aiming to interpret $i^{30,31}$.

\section{Study location and participants}

The inclusion criterion to participate in the study sample was: an individual who was attending the fourth year (annual entry) or eighth semester (semester entry) of one of the Schools of Medicine in the state of Goiás, Brazil. This state is located in the Midwest region of Brazil and has a population of 6 million inhabitants ${ }^{32}$.

In Brazil, the undergraduate course in Medicine has a minimum workload of 7,200 hours and a minimum period of six years for its completion, with the last two years being characterized by a mandatory curricular internship for inservice training, called medical internship ${ }^{2}$. Therefore, it was an intentional choice ${ }^{28}$ to set up a focus group with students who had already completed most of their undergraduate courses before starting their internship.

During the research period, four Higher Education Institutions (HEls) had a medical course ${ }^{33}$. However, the study was conducted in only three HEls: Universidade Federal de Goiás (UFG), Centro Universitário de Anápolis (UniEvangélica) and Pontifícia Universidade Católica de Goiás (PUC Goiás), because in the fourth medical course, the students were still attending the initial years/semesters during the research period ${ }^{33}$.

The federal public institution, created in 1960, uses a traditional teaching methodology with some curriculum innovations since $2003^{33,34}$. In the other two private institutions, the Medicine courses were created after the publication of the National Curriculum Guidelines for Undergraduate Courses in Medicine by the National Council of Education, in 2001, implementing curricula with active teaching methodologies, such as problem-based learning ${ }^{33,35}$.
Participants were recruited through a previous contact, which was initiated with the secretaries of the medical courses to obtain the list of students who met the inclusion criteria. The studied sample was randomly selected by drawing lots via Microsoft ${ }^{\circledR}$ Software Office Excel ${ }^{36}$. The students were invited by telephone to discuss a topic on medical education, with no reference to the specific thematic.

Eighteen students were invited from each institution to ensure that each focus group had between four and twelve participants ${ }^{25,28}$, considering unforeseen events, absences and impediments to the presence of confirmed students on the scheduled day.

\section{Data collection}

Considering the participation of medical courses in the research, three focus groups were carried out with students from the same institution between October and December 2013. The focus groups took place in adequate rooms at the respective Higher Education Institution at a time compatible with the students' availability. The researcher, responsible for conducting the focus groups, took on the concomitant roles of moderator, spokesperson and audio operator.

The debate script was established based on the literature on the addressed topic and on the research goals. The guiding questions were submitted to a pilot test after the recruitment of a sample consisting of fifth-year students (Internship 1). Table 1 shows the script of questions used to conduct the focus groups, which correspond to the categories created a priori.

Each focus group was completed when the saturation of the proposed topic was reached, as the data representativeness was not of interest, but rather the diversity and depth of the information ${ }^{28}$. All focus group discussions were audio-recorded and transcribed in full.

\section{Data analysis}

The Atlas.TI software version $7.0 .77^{37}$ was used in the data analysis, after the speeches of the focus groups were transcribed, to select similar ones, facilitating the coding organization and data categorization. The focus groups received a code with the initial letter of the words "Focus Group"

Table 1. Debate script on feedback for conducting focus groups

\section{About feedback during undergraduate school:}

\footnotetext{
1. Have you ever heard about the feedback or the feedback technique in evaluation? What do you understand about this subject?

2. Did you receive feedback at any point during the training? At what times? What was the frequency?

3. Was the amount of received feedback sufficient during the training? Why?

4. Did this feedback contribute to your learning/training? Justify your answer.
} 
(FG) followed by the number 1 or 2 or 3 , sequentially identifying the institutions: UniEvangélica, UFG and PUC/Goiás; ensuring the anonymity of participating students.

Data analysis was performed using the thematic content analysis technique based on Minayo et al. ${ }^{30}$ and Bardin ${ }^{31}$.

The four researchers analyzed the transcripts using an inductive process. After the initial independent reading, a meeting was held to compare the respective notes. This cycle of reading and meeting to discuss the data was repeated until the group reached a consensus on the categories and subcategories that emerged from the participants' discourses. The results were later treated through inferences and possible interpretations. All members of the research team, including three women and one man, of which three had a Ph.D. and one a Master's Degree during the research period, are engaged in projects related to medical education, including the evaluation of the actual educational impact of feedback on the teaching-learning process.

All methodology was performed by applying precise rules (confirmation, credibility, security and transfer) in order to guarantee scientific stringency $y^{24-26,38,39}$.

\section{Ethical aspects}

Data collection started after approval by the Research Ethics Committees of the proposing institution and of the two co-participating institutions, under registration number 14771213.9.0000.5078 in the Certificate of Presentation for Ethical Appraisal (CAAE) of Plataforma Brasil.

The focus groups were held after the participating students agreed with the research purposes and signed the Free and Informed Consent form. The study was developed considering ethical precepts according to Resolution N. 466/12 of the Brazilian National Health Council ${ }^{40}$.

\section{RESULTS}

Considering the three focus groups, the study included 25 students from the participating Medicine courses. The students were aged between 20 and 24 years, of which 11 were men and 14 women. The duration of the focus group debate lasted from 60 to 90 minutes.

The results from the categories established a priori and the subcategories obtained from the thematic analysis of the speeches of participants in the focus groups conducted according to the debate script are shown below:

\section{Understanding of feedback}

Students from all institutions said they understood the meaning of feedback, but there was some difficulty in defining it. Examples were pointed out to characterize the definition, in which the teacher is usually the external source of feedback, with the role of highlighting the positive points, pointing out errors and teaching how to do it correctly:

A teacher will explain to the student what they did wrong, ask them why they did it wrong, what was the difficulty they found in that subject or problem and try to solve it. (FG1)

A teacher will show me what I did wrong, how I did it, what I could do better and also highlight some positive aspects. (FG2)

You did it wrong, here is the right way to do it. Change sides because you are not on the right path. You got it right, stay on that path. (FG3)

The reflective function in the feedback process, that is, the internal feedback, was not pointed out by the students.

\section{Frequency of received feedback}

There was a consensus that there were few moments of feedback experienced during the course, leading to dissatisfaction and a call for improvement by the students:

Even though there is a formative assessment, it is only on paper. We don't know why we received that grade. Feedback doesn't always happen. There are only a few moments, it could be better. (FG1)

The frequency is practically nil, I remember rare moments when I received feedback. I am close to finishing the fourth year and going on to internship, so I think it was totally insufficient. I think it has to improve a lot. (FG2)

The frequency is not that high, it is lower, because we are constantly evaluated here at the university. Everything we do is submitted to an evaluation. I think it really needs to be improved. (FG3)

The frequency was also related to the teacher and/or discipline and time in the course and the curriculum model:

As we evolve during the course, the importance of formative assessment diminishes. In the beginning, feedback was more related to the tutoring. (FG1)

I consider that I started getting more feedback this year, after the fourth year, because before what I had were the test answers, it wasn't really feedback. (FG2)

From the beginning to almost half of the 3rd year, mainly in tutoring activities, which we had and no longer have. (FG3)

Once in a while a teacher gives a nice feedback. It also depends on the discipline: there are some that do and others that don't. (FG3)

According to the participants, the discipline of Pediatrics was the one with the highest frequency of feedback in all institutions: 
In Pediatrics, we had a lot of feedback. The teachers help us more, tell you how you have to do it. It is much better this way. (FG1)

The most frequent and positive feedback we had so far during undergraduate school was during Pediatrics. (FG2)

I loved Pediatrics. They always gave us feedbacks and these were always very relevant. (FG3)

\section{Impact of feedback on the learning process}

Despite the low frequency, the participants realized that feedback was very important for the teaching-learning process. They demonstrated this opinion by highlighting the positive individual impacts (emotional state, cognitive ability and performance) and their relevance in improving the teachinglearning environment.

They also recognized that the feedback generated emotional impacts: security about what was learned, serenity, a sense of well-being and motivation to study:

Feedback in Pediatrics was a highlight. So much so that I, at least, have that security and I think everyone here has, to take care of a child these days and not feel so insecure about what you are doing. (FG2)

There are things I remember to this day that I know. For instance, when they ask me something and after that, they say: "Are you sure?" I am, because once I said such and such and the teacher said it was wrong and the right one was such and such a thing. So this is very important. (FG1)

In evaluations, you are always nervous. We are tested regarding every point. After you finish the evaluation, when they value and praise what you did right, that is something that makes you feel calmer and at the same time, you are sure that the mistake you made, you will not make anymore. It reassures us a lot! (FG2)

You may also still have doubts, you are learning, you are still at the university. If you get it wrong after you finished it, that is one thing, but you can still get it wrong in here. (FG3)

You really feel so good when they say: "you did not do well in this aspect and all, but you did well in this other point.' (FG1)

Teachers who are concerned about giving feedback do it very well, because it is very good to encourage the student to be interested in what was wrong and try to learn for real. (FG2)

From a cognitive point of view, the students stated that the feedback consolidated learning, making it more effective and preventing simple memorization; helped to build knowledge, enabling awareness of what is right and wrong; facilitated reasoning and decision-making in similar cases, reducing the chances of future errors; made it easier to put theory into practice and learn from the mistakes of others:

It is a very effective form of teaching. [...] when you make a mistake, you learn what is right if someone orients you and that becomes even more consolidated. So, for instance, you saw that you made a mistake and you end up learning it for real, without having to memorize it. It is very difficult for you to get that wrong again when experiencing the same situation. If I had not received the feedback, I wouldn't remember. (FG2)

As the feedback technique is not only to criticize mistakes, but also to reinforce what you got right, I think this is very important because we do it there and don't even realize what we did. (FG2)

At a similar next opportunity the student will be able to reason alone and get it right. (FG1)

Another thing is for the teacher to say: it is better to do it this way because the patient will understand it better. This may be described in the book, but we cannot understand it alone, cannot do it not correctly. And when the teacher directs you, it is easier to understand and put into practice. (FG1)

When a mistake is made by many students, the teacher speaks collectively. Perhaps even if you are not making a mistake or you haven't had a moment to make that mistake, you might. (FG3)

The participants reported that there was an improvement in performance regarding activities due to the opportunity for correction and the acquisition of skills such as a better doctorpatient relationship through feedback:

If I know what I did wrong and how to do it right, next time I will do it the best way I can. (FG1)

Feedback was very important in this period of transition from theory into practice because it was through it, highlighting the positive and negative points of meeting the first patients, that we were able to learn how to establish a good doctor-patient relationship. (FG2)

As for the teaching-learning environment, the students highlighted that the feedback improved the student-teacher relationship; stimulated students' participation; guided learning and helped to homogenize the class, facilitating the course of the learning:

We have teachers who sit and talk. Everyone sat down, they provided orientation and accepted the things that were good to follow. Feedback is sometimes a conversation, it ends up bringing students and teachers closer together. That makes you participate more in class, interact both with your classmates and teachers. It is not just the teacher pouring out knowledge, but the students contributing to the 
formation of their own knowledge and that of their classmates.' (FG3)

He wanted to discuss performance because some of the classmates were having difficulties, and after doing that, he got everyone to go ahead. (FG3)

It serves to show whether we are on the right path or not, whether we are studying the right way or not. It guides our learning and shows the teacher and us how to proceed. (FG2)

\section{Perception about the received feedback}

There was an agreement that the feedback, being effective, was well accepted by the students:

She (the teacher) sat down with me one day and told me some things, individual feedback, and I think that has changed. It was good. Important. (FG3)

I think it was very positive because it is a very effective way of teaching. (FG2)

The quality feedbacks received contributed to our learning and training. (FG1)

\section{DISCUSSION}

Students demonstrated a partial understanding of the meaning of feedback. They did not stress the importance of internal feedback, nor did they address the existence of other important sources of external feedback in addition to the teacher. This may explain the reported low frequency of feedback and its relationship to the teacher, the discipline or time in the course and type of curriculum. On the other hand, the participants recognized the impacting points of feedback on the teachinglearning process, being receptive to effective feedback.

The study by Poulos et al. ${ }^{41}$ with several courses in the health area also observed a difficulty in homogeneously defining what it is and how to use feedback. Similarly, Hounsell et al. ${ }^{42}$ found that the students recognized the importance of extrinsic feedback in performing specific tasks, but, as in the present study, they were unable to formulate the intrinsic feedback based on the daily activities of the teaching-learning process.

Bowen et al..$^{43}$ conducted a study with focus groups in which they gave undergraduate medical students a map of key feedback opportunities throughout the program. The participants indicated that signaling has the potential to better prepare students to recognize feedback. However, they were confused by the feedback they received and stated they did not receive the potentially available amount of feedback, also revealing the difficulty in recognizing the feedback.

Diversely, online undergraduate students in the health area, in the study by Getzlaf et al. ${ }^{44}$, recognized feedback as a process of mutual contributions, both by undergraduates and teachers. Students wanted to be involved in the planning of feedback regarding learning objectives, areas that needed improvement, and appropriate time for feedback. The authors highlighted that this viewpoint involves power sharing between students and teachers, something that is not common in higher education. In the study by Maia et al. ${ }^{45}$, the authors also concluded the study by reporting that students understand feedback, but throughout the presented work, they did not make it explicit how it happens.

Recognizing internal feedback as a metacognitive process, in which the students are aware of how they learn better, how they learn satisfactorily and also evaluate the effectiveness of the strategies they use, makes it an inextricable step from the intentional learning process ${ }^{12,13}$.

Internal feedback works like the metacognitive system described by Nelson et al ${ }^{46}$ : two interrelated levels (object level and meta level) through a continuous flow of information (control and monitoring) ${ }^{46}$. The object level is the task itself (where the task is performed) and the meta level is the task at the ideal level resulting from a process of personal construction that can be modified and improved. Monitoring is the flow in which object-level events can be identified and compared to the pre-existing meta level task model (adequate or not). Control is the flow that the meta level corrects or confirms the actions at the object level (modifies) and makes efforts to start, continue or finish the task ${ }^{12,46}$.

This metacognitive system correlates with the metacognitive structure proposed by Flavell ${ }^{11}$. The metacognitive knowledge refers to the quality of information sent at the meta level, both about the person (knowledge and beliefs acquired as cognitive processors, affecting how one copes with learning difficulties), the task (knowledge about complexity and requirement) and strategy (the existence of different means to reach the intended cognitive objectives, being aware of the similarities and differences between them and when and where each one should be used). Metacognitive ability refers to the functioning of this metacognitive system. The metacognitive experience is the context in which feelings (affective) and awareness (cognitive) are involved in the process ${ }^{11,12}$.

The effectiveness of learning does not depend only on age, experience and cognitive level, but includes the acquisition of cognitive and metacognitive strategies that allow students to plan and monitor their performance, that is, it allows them to become aware of the processes they use to learn and make appropriate decisions about which strategies to use in each task and also to assess their effectiveness, changing them when they do not produce the desired results ${ }^{47}$.

Regarding the actual frequency of feedback in the teaching-learning process, there are different opinions by 
teachers and students. Carless ${ }^{19}$ highlighted that $38.4 \%$ of teachers believed they frequently gave detailed feedback, which helped students improve their performance, while only $10.6 \%$ of the students had the same perception.

As in the present study, Watling et al. ${ }^{20}$ found a lack of a feedback culture in the medical course, reporting the deficient feedback frequency in medical education when compared to music and pedagogy courses. In another study, Watling et al. ${ }^{18}$ observed that in areas of high training level such as sports and music, feedback is part of the routine and has a central role in learning; however, in medical education, it is marginalized and the medical students in the sample also felt the lack of feedback during undergraduate school.

On the other hand, in the study by Bates et al. ${ }^{48}$, medical students attending the longitudinal clinical internship acknowledged more often receiving an informal feedback from their tutors in their daily lives during patient care.

The different perceptions of students regarding the occurrence of feedback throughout the course from the perspective of the institution's curriculum, mentioned herein, may be related to the fact that feedback is one of the steps in the problem-based learning methodology ${ }^{49}$, with greater observance of methodological rigor in the initial years of the course $^{50}$. Differently, in the traditional methodology in which disciplines are divided into basic and professional cycles ${ }^{51}$, students only have contact with feedback when they go into the professional cycle, in the final years of the course.

Miranda et al. $^{52}$, carried out a study on feedback with a quantitative approach in a Brazilian medical education institution, which used the problem-based learning methodology in the curriculum. It found that up to $95 \%$ of students in the first semesters confirmed the performance of the feedback, whereas $100 \%$ of the students attending the fifth semester and $56.45 \%$ of those attending the eighth semester denied its performance. In a medical school in the United Kingdom, where the early years corresponded to the basic cycle of medical sciences and the final years to the clinical cycle, students in the early years had greater difficulty in recognizing feedback, while students attending the more advanced years of the course consciously looked for feedback ${ }^{43}$.

About the important role of the discipline of Pediatrics in the context of feedback in this study, it can be seen as a local characteristic, in which the schools shared the same professionals or professionals who had the same training, allowing the dissemination of the practice of feedback among the institutions. However, it can also be related to the characteristic of this medical specialty in dealing with communication skills with adolescents, facilitating the adoption of andragogical practices in the teaching-learning environment.
In the study by Bowen et al. ${ }^{43}$, the students described positive relationships with supervisors and their perceptions that these teachers were hardworking as the main determinants of the feedback process: recognition, involvement and credibility.

There is also some discussion regarding the perception of students about the received feedback. Bailey ${ }^{21}$ and Carless ${ }^{19}$ demonstrated the students' negative perception about the usefulness of feedback, especially when its quality was considered poor. Other studies ${ }^{41,43-45,52-56}$ demonstrated that students valued effective feedback and its important role in the teaching-learning process, as observed in the present study.

In addition to the fact that feedback is central to the cognitive process, there are some studies ${ }^{4,14,57-59}$ that reaffirmed its importance in supporting technical and professional performance: encouraging the student to perform well, ensuring the quality of patient care and their safety, essential for the acquisition of professional skills (communication skills, clinical examination, prescription, empathy, professionalism and teamwork) and encourage professional practice focused on results and continuous professional development.

For Getzlaf et al. ${ }^{44}$, the students recognized that constructive and positive feedback helped them to feel safe and to develop confidence, being a motivating experience for learning, as shown in the present study. Moreover, participating students recognized the importance of feedback for future practice in two dimensions: identifying areas that need improvement and the triggering of an action plan during undergraduate school and applying the received feedback to the future professional life, avoiding mistakes and facilitating the application of theory on new practical experiences.

In the study by Bates et al. ${ }^{48}$, the informal feedback that emerged from the daily clinical supervision of the longitudinal clinical internship promoted a supportive and caring relationship between tutors and students, contributing to the development of a sense of security, capacity to generate internal feedback and better acceptance of negative feedback.

Therefore, it is possible to list three elements involved in the feedback process: the teacher, the student and the institution. The institutions focus on improving the teachers' ability to provide feedback, but few focus on how to involve students in the process. Believing that feedback is a skill exclusive to teachers is a myth ${ }^{60}$.

Feedback must be a process, a dialogue between the provider and the receiver, important in itself, ensuring that the message was received, how it was interpreted and how it needs to be contextualized and put into practice in a new opportunity ${ }^{4,61}$. The student must also be trained in the practice of reflective feedback, developing a process of selfmonitoring of learning ${ }^{8}$. 
As reported in this study, students only partially understood the meaning of feedback, not recognizing internal feedback. If even with the low frequency of feedback reported in the study, students recognized the impact of feedback on the learning process, in a context of students capable of knowing about their own knowledge, truly empowering them in the teaching and learning process, they will develop a constant reflective practice of generating internal feedback, allowing the real impact of feedback on the teaching and learning process to be observed in practice as described in the literature.

This study showed a selection bias as limitation, as it assessed a randomized sample extracted from a specific group of medical students, exposing only their point of view on educational feedback, which may contain elements that are less representative of their social group in their speech as a whole, that is, the perception of other students may have different elements.

Notwithstanding, the number of participants in each focus group and the recorded speeches disclosed a homogeneous opinion on the subject and there was saturation of the collected data, meeting the actual aim of this study, which lies in the depth and value of the collected information. We are not suggesting that results will be true in other contexts, since representativeness is linked to specific contexts and not to the representation of a population ${ }^{25,28}$.

Intervention studies aimed at preparing students for this metacognitive path, facilitating the formation of internal feedback, must be carried out to assess this important learning strategy in the context of medical education.

\section{CONCLUSIONS}

The present study showed that the students had difficulty in conceptualizing feedback; they partially understood it, lacked the concept of internal feedback. They were able to recognize the importance of feedback for their learning process and were receptive to effective feedback. However, they resented the low frequency of feedback and the lack of regulation regarding the use of this tool.

Based on the students' perception, the feedback occurred irregularly and depended on the teacher or the discipline, regardless of whether the institution was public or private and the current curriculum model.

Thus, to train students and teachers to fully know about and understand feedback, in the metacognitive context, and stop focusing on external feedback only, considering the model used in professional practice of indicating solely what should be done, can potentially fill the gap between theory and practice regarding the actual power that feedback has in the teachinglearning process.

\section{AUTHORS' CONTRIBUTION}

Silvia Cristina Marques Nunes Pricinote and Edna Regina Silva Pereira developed the concept and design of the research project; collected, analyzed and interpreted the data; wrote and critically revised the manuscript to ensure the study had important intellectual content. Nilce Maria da Silva Campos Costa and Marcos Rassi Fernandes analyzed and interpreted the data; wrote and critically revised the manuscript to ensure the study had important intellectual content.

\section{CONFLICTS OF INTEREST}

The authors declare no conflicts of interest.

\section{SOURCES OF FUNDING}

The authors declare no sources of funding.

\section{REFERENCES}

1. Zeferino $A M B$, Passeri SMRR. Avaliação da aprendizagem do estudante. Cadernos da ABEM. 2007;3: 39-43.

2. Brasil. Resolução n 3, de 20 de junho 2014. Institui Diretrizes Curriculares Nacionais do Curso de Graduação em Medicina. Diário Oficial União; 23 jun 2014 [access in 13 aug 2020]. Available from: https://pesquisa.in.gov.br/imprensa/jsp/visualiza/index jsp?data=23/06/2014\&jornal=1 \&pagina=8\&totalArquivos $=64$.

3. Peixoto MAP, Silva RNMB. Estratégias de aprendizagem em alunos de medicina: pré-teste. Rev Bras Educ Med. 1999;23(1):18-31.

4. Hattie J, Timperley $\mathrm{H}$. The power of feedback. Rev Educ Res. 2007;77(1):81-112.

5. Stone A. Online assessment: what influences students to engage with feedback? Clin Teach. 2014;11(4):284-9.

6. Archer JC. State of science in health professional education: effective feedback. Med Educ. 2010;44(1):101-8.

7. Iskander M. Offering effective feedback to trainees. Med Teach. 2015;37(1):92-3.

8. Nicol DJ, Macfarlane-Dick D. Formative assessment and self-regulated learning: a model and seven principles of good feedback practice. Studies in Higher Education. 2006;31(2):199-218.

9. Burr S A, Brodier E, Wilkinson S. Delivery and use of individualized feedback in large class medical teaching. BMC Med Educ. 2013;13(1):63.

10. Kolb D, Fry R. Towards an applied theory of experiential learning. In: Cooper $\mathrm{CL}$, editor. Theories of group processes. London: John Wiley; 1972. p. 33-58.

11. Flavell $\mathrm{JH}$. Metacognition and cognitive monitoring: a new area of cognitive-development inquiry. Am Psychol. 1979;34(10):906-11.

12. Peixoto MAP, Brandao MAG, Santos G. Metacognição e tecnologia educacional simbólica. Rev Bras Educ Med. 2007;31(1):67-80.

13. Jou GI, Sperb TM. A metacognição como estratégia reguladora da aprendizagem. Psicol Reflex Crit. 2004;19(2):177-85.

14. Ramani S, Krackov SK. Twelve tips for giving feedback effectively in the clinical environment. Med Teach. 2012;34(10):787-91.

15. Norcini J. The power of feedback. Med Educ. 2010;44(1):16-7.

16. Ramani S. Reflections on feedback: closing the loop. Med Teach 2016;38(2):206-7.

17. Murdoch-Eaton D, Bowen L. Feedback mapping - the curricular cornerstone of an "educational alliance". Med Teach. 2017;39(5):540-7.

18. Watling C, Driessen E, van der Vleuten CPM, Lingard L. Learning culture and feedback: an international study of medical athletes and musicians. Med Educ. 2014;48(7):713-23. 
19. Carless D. Differing perceptions in the feedback process. Studies in Higher Education. 2006;31(2):219-33.

20. Watling C, Driessen E, van der Vleuten CPM, Vanstone M, Lingard L. Beyong individualism: professional culture and its influence on feedback. Med Educ. 2013;47(6):585-94.

21. Bailey R. Undergraduate students' perceptions of the role and utility of written assessment feedback. Jldhe. 2009;1:1-14.

22. Kluger A, Denisi A. The effects of feedback interventions on performance: a historical review, a meta-analysis, and a preliminar feedback intervention theory. Psychol Bull. 1996;119(2):254-84.

23. Bing-You R, Hayes V, Varaklis $K$, Trowbridge R, Kemp H, McKelvy D. Feedback for learners in medical education: what is known? A scoping review. Acad Med. 2017;92(9):1346-54.

24. O'Brien BC, Harris IB, Beckman TJ, Reed DA, Cook DA. Standards for reporting qualitative research: a synthesis of recommendations. Acad Med. 2014;89 (9):1245-51.

25. Gray DE. Doing research in the real world. 3rd ed. London: Sage; 2014.

26. Ramani S, Mann K. Introducing medical educators to qualitative study design: twelve tips from inception to completion. Med Teach. 2016;38(5):456-63.

27. Godoy AS. Pesquisa qualitativa: tipos fundamentais. Revista de Administração de Empresas. 1995;35(3):20-9.

28. Stalmeijer RE, Mcnaughton N, Van Mook WNKA. Using focus groups in medical education research: AMEE Guide $n^{\circ}$ 91. Med Teach. 2014;36(11):923-39.

29. lervolino AS, Pelicioni MCF. A utilização do grupo focal como metodologia qualitativa na promoção da saúde. Rev Esc Enferm USP. 2001;35(2):115-21.

30. Minayo MCS, Deslandes SF, Gomes RC. Pesquisa social: teoria, método e criatividade. 34a ed. Petrópolis: Vozes; 2015.

31. Bardin L. Análise de conteúdo. São Paulo: Edições 70; 2011.

32. Instituto Brasileiro de Geografia e Estatística. Atlas do censo demográfico 2010. Rio de Janeiro: IBGE; 2013.

33. Nassif ACN. Escolas médicas por estados. Curitiba: Escolas médicas do Brasil [access in 30 aug 2020]. Available from: http://www.escolasmedicas. com.br/escolas-medicas-estado.php.

34. Universidade Federal de Goiás. Projeto pedagógico. Goiânia: UFG; 2014 [access in 30 aug 2020]. Available from: https://www.medicina.ufg.br/ p/1678-projeto-pedagogico.

35. UniEvangélica Centro Universitário. Projeto pedagógico de curso: Medicina. Anápolis: UniEvangélica; 2017 [access in 30 aug 2020]. Available from: http://v2.unievangelica.edu.br/wp-content/uploads/2018/10/ medicina-ppc.pdf.

36. Microsoft Corporation. Microsoft Office Excel for Windows 7. Version 2007. Redmond, WA: Microsoft Corporation; 2007.

37. Atlas.ti Scientific Software Development GmbH. Scientific Software: qualitative data analysis. Version 7.0.77. Berlin: Atlas.ti Scientific Software Development GmbH; 2012.

38. Boet S, Sharma S, Goldman J, Reeves S. Review article: medical education research: an overview of methods. Can J Anaesth. 2012;59(2):159-70.

39. Frambach JM, van der Vleuten CPM, Durning SJ. AM last page: quality criteria in qualitative and quantitative research. Acad Med. 2013;88(4):552.

40. Brasil. Resolução $n^{\circ} 466$, de 12 de dezembro de 2012. Aprova as diretrizes e normas regulamentadoras de pesquisa envolvendo seres humanos. Diário Oficial União; 13 jun 2013. Seção 1, p. 59 [access in 13 aug 2020]. Available from: https://pesquisa.in.gov.br/imprensa/jsp/visualiza/index. jsp?jornal=1\&pagina $=59 \&$ data $=13 / 06 / 2013$.
41. Poulos A, Mahony MJ. Effectiveness of feedback: the students' perspective. Assess Eval High Educ. 2008;33(2):143-54.

42. Hounsell D, McCune V, Hounsell J, Litjens J. The quality of guidance and feedback to students. Higher Education Research \& Development. 2008;27(1):55-67.

43. Bowen L, Marshall M, Murdoch-Eaton D. Medical student perceptions of feedback and feedback behaviors within the context of the "educational alliance". Acad Med. 2017;92(9):1303-12.

44. Getzlaf B, Perry B, Toffner G, Lamarche K, Edwards M. Effective instructor feedback: perceptions of online graduate students. The Journal of Educators Online. 2009;6(2):1-22.

45. Maia IL, Kubrusly M, Oliveira MCX, Oliveira CMC, Augusto KL. Estratégia adaptada de feedback voltado para ambulatórios de graduação Rev Bras Educ Med. 2018;42(4):29-36.

46. Nelson TO, Narens L. Why investigate metacognition? In: Metcalfe J, Shimamura AP, editors. Metacognition: knowing about knowing. Cambridge: The MIT Press; 1994.

47. Romanowski JP, Rosenau LS. A contribuição dos processos metacognitivos na formação do pedagogo. Intersaberes, 2006;1(1):8-27.

48. Bates J, Konkin J, Suddards C, Dobson S, Pratt D. Student perceptions of assessment and feedback in longitudinal integrated clerkships. Med Educ. 2013;47(4):362-74.

49. Azer SA. Introducing a problem-based learning program: 12 tips for success. Med Teach. 2011;33(10):808-13.

50. Azer SA, Mclean M, Onishi H, Tagawa M, Scherpbier A. Cracks in problembased learning: what is your action plan? Med Teach. 2013;35(10):806-14.

51. Pagliosa FL, Da Ros MA. O relatório Flexner: para o bem e para o mal. Rev Bras Educ Med. 2008;32(4):492-9.

52. Miranda GRN, Pessoa TF, Marco LBMM, Borges ACB, Neves BLS, Miotto $I A$, et al. Desafios do feedback na avaliação formativa, no programa interinstitucional de interação ensino-serviço-comunidade: perspectiva de alunos. Rev Bras Educ Med. 2020;44(4):e122.

53. Hounsell D. Student feedback, learning and development. In: Slowey M, Watson $D$, editors. Higher education and the lifecourse. Buckingham, UK: Society for Research into Higher Education \& Open University Press; 2003, p. 67-78.

54. Orsmond $\mathrm{P}$, Merry S, Reiling K. Biology students' utilization of tutors' formative feedback: a qualitative interview study. Assess Eval High Educ. 2005;30(4):369-86.

55. Doan L. Is feedback a waste of time? The students' perspective. Journal of Perspectives in Applied Academic Practice. 2013;1(2):3-10.

56. Zimmermann MH, Silveira RMCF, Gomes RZ. O professor e a arte de avaliar no ensino médico de uma universidade no Brasil. Rev Bras Educ Med. 2019;43(3):5-15.

57. Veloski J, Boex JR, Grasberger MJ, Evans A, Wolfson DB. Systematic review of the literature on assessment, feedback and physician's clinical performance: BEME Guide n 7. Med Teach. 2006;28(2):117-28.

58. Zeferino AMB, Domingues RCL, Amaral E. Feedback como estratégia de aprendizado no ensino médico. Rev Bras Educ Med. 2007;31(2):176-9.

59. Cushing A, Abbott S, Lothian D, Hall A, Westwood OMR. Peer feedback as an aid to learning - what do we want? Feedback. When do we want it? Now! Med Teach. 2011;33(2):e105-12.

60. Molloy E, Ajjawi R, Bearman M, Noble C, Rudland J, Ryan A. Challenging feedback myths: values, learner involvement and promoting effects beyond the immediate task. Med Educ. 2020;54(1):33-9.

61. Murdoch-Eaton D. Feedback: the complexity of self-perception and the transition from "transmit" to "received and understood". Med Educ. 2012;46(6):538-40. 